\title{
Review of Books
}

\author{
Edited by Tommaso Natoli
}

Flavia Zorzi Giustiniani, International Law in Disaster Scenarios - Applicable Rules and Principles' (Springer 2021), xiv, 209 pages, ISB N 978-3-030-50596-7

Natural hazards and manmade disasters in recent years have continuously gained the attention of the international community due to their increasing occurrence around the world. Apart from the "traditional" forms of disasters, such as those provoked by floods, earthquakes, or droughts, we are currently facing many challenges in eliminating an ongoing global health emergency the COVID-19 pandemic. An occurrence of these extraordinary situations brings with it numerous aspects that Public International Law, and specifically International Disaster Law (IDL), increasingly address. Even though disasters affect States and their populations since time immemorial, the identification of applicable rules and principles to address them is characteristic for the last decades. Hence, the scientific literature on International Disaster Law is gradually growing, and a greater number of legal scholars address today various aspects of this discipline. One of the newest additions in this area is the book "International Law in Disaster Scenarios - Applicable Rules and Principles" by Flavia Zorzi Giustiniani.

The study has a logical structure, which starts with a brief 'Introduction' to the subject illustrating the gradual development of the relevant institutional and legal frameworks for disaster response, such as the creation of the International Relief Union, which still constitutes the only international agreement of universal character in disaster response. Specific attention regarding the legal framework for disaster response is focused on the codification works carried out under the aegis of the International Federation of Red Cross and Red Crescent Societies (IFRC) and the UN International Law Commission (ILC). The IFRC's contribution in this area is highlighted by the drafting of the Guidelines for the Domestic Facilitation and Regulation of International Disaster Relief and Initial Recovery Assistance (IDRL Guidelines) and the Model Act for the Facilitation and Regulation of International Disaster Relief and Initial Recovery Assistance (Model Act). Although these documents are 
non-binding, due to their many technical provisions, States are gradually implementing them into their domestic legal systems, ${ }^{1}$ which has a particularly positive impact on States' future disaster response. This is especially beneficial when assistance is offered by States or international humanitarian actors, so that norms on disaster response are progressively harmonising.

Great attention, not only in the introductory part but throughout the entire study, is given to the ILC's Draft Articles on the Protection of Persons in the Event of Disasters (hereinafter 'Draft Articles'), which contributes to the consolidation and the development of international norms applicable to disasters, notably regarding the role of the affected State in disaster response and States' obligations concerning the prevention of disasters. A distinctive and welcome feature of the text concerns its recipients which, contrary to most existing treaties governing disaster response, are not just States but also the different actors making up the broad humanitarian community. ${ }^{2}$ It is important to highlight the author's thorough analysis of the above mentioned document, especially the parts relevant to the rules and principles analysed in this book. Furthermore, it is highly appreciated that the author in this part of the book not only mentions the definition of 'disaster', which may be found in numerous legally binding and non-binding documents, but also offers her understanding of this pivotal category. Disasters thus may be defined as situations of international relevance that result from the unwillingness or inability of the affected State, region, or society to cope with the disaster by using only its own resources. ${ }^{3}$ Overall, the 'Introduction' is particularly helpful for those scholars who are beginning to explore IDL and are interested in understanding the recent evolutions in this evolving branch of Public International Law.

Then, the book is divided into 4 thematic 'Parts'. Selected general and preliminary observations concerning the international legal framework applicable in disaster scenarios are outlined in Part I ('International Law and Disaster Response: The Applicable Legal Framework'). The constantly growing number of legally binding instruments, especially regional treaties, is supplemented by a considerable number of legally non-binding instruments that are supportive in, for instance, technical aspects of assistance to the disaster-affected State and their population. This part not only analyses the internal scope of IDL, in the sense of pure norms and principles of IDL but also focuses on its external scope,

1 IFRC, 'Fourth Progress Report on the Implementation of the IDRL Guidelines' (2019), available at <https://media.ifrc.org/ifrc/wp-content/uploads/sites/5/2019/11/2019112O_IDRL _ONLINE_Sized.pdf $>$, last accessed (as any subsequent URL) on 10 April 2021.

2 Flavia Zorzi Giustiniani, International Law in Disaster Scenarios - Applicable Rules and Principles (Springer 2021) 11.

3 Ibid., 201. 
defining the relationship with other branches of Public International Law, namely International Human Rights Law (IHRL) and International Humanitarian Law $(\mathrm{IHL})$, regarding the application of relevant rules and principles in the disaster situations. The author concludes that the rules applicable to disaster contexts cannot be contained within the boundaries of any given regime. The applicability of rules and principles in disaster scenarios is even more intricate in situations of complex emergencies, meaning the simultaneous occurrence of disaster within a territory where an armed conflict is carried out. As mentioned by the author, in complex emergencies, IHL norms cannot be and indeed are not the only rules to apply. Given the multiplicity of subjects acting in such contexts - mainly States, armed groups, and humanitarian organisations of both intergovernmental and non-governmental character - and the scarcity of customary norms specifically addressing disasters, the applicable framework is necessarily variegated and case-specific. ${ }^{4}$ As it is emphasised, the choice of the applicable legal framework should be made at the level of single norms and on a case-by-case basis, taking into account the following factors: a) the level of detail of the norms and the more or less precise scope of their application; b) the nexus of the situation with the armed conflict or the disaster; c) the geographical proximity of the disaster to areas of active hostilities; and, d) ultimately, the exigencies of military necessity. ${ }^{5}$

In the second part ('The Role of the State Hit by the Disaster'), the author analyses a set of rules and principles of International Law that are closely connected with the role of the disaster-affected State. From the legal perspective, the key principle that is applicable here is the notion of state sovereignty, which has several forms in disaster response. Traditionally, the disasteraffected State exercises its sovereignty within the protection of its population and in the direction, control, coordination, and supervision of international assistance provided by other States, intergovernmental organisations, or non-state actors. In this regard, the author focuses on the legal aspects of the initiation of disaster assistance, such as the consent of the disaster-affected State, notification, requests, and offers of international assistance. In disaster scenarios, it is fairly common that the international community offers and provides international assistance to the disaster-affected State. However, the role of external action needs to be complementary to that of the affected State so as not to undermine national capacities and responsibilities and disempower the affected population. ${ }^{6}$ The 2004 Indian Ocean Tsunami or the 2010 earthquake

4 Ibid., 50-51.

5 Ibid., $5^{\circ}$.

6 Ibid., 202. 
in Haiti are typical examples, where the application of sovereign rights of disaster-affected States was interfered with by some humanitarian actors, who bypassed the local authorities. This aspect of State sovereignty is analysed through the retention of national control, compliance with international and national rules and standards. The most cited example, in this regard, is the notorious 'Nargis case', which is frequently analysed in IDL literature, principally due to the potential application of the 'Responsibility to Protect' (R2P) doctrine. Interestingly, the author offers her personal perspective on the case, which highlights the importance of State consent whatever the circumstances and however grave the crisis and concludes that international cooperation and solidarity (through regional economic integration organisations) are much more effective than muscular humanitarianism. ${ }^{7}$ R2P has been invoked several times in disaster settings, and its application in such contexts, despite the persistent opposition of many States, cannot be excluded a priori ${ }^{8}$

The third part ('International Cooperation and Solidarity in Disasters') elaborates on rules and principles that are associated with assisting States, international organisations, and other actors, namely international cooperation and solidarity, which are especially important in times of disasters. A comparison of several theories from legal and philosophical scholars, such as Vattel, ${ }^{9}$ Duguit, ${ }^{10}$ Scelle, ${ }^{11}$ Alvarez, ${ }^{12}$ or Michels, ${ }^{13}$ is very valuable since it offers an interdisciplinary view on international cooperation and solidarity throughout several time eras, which inevitably gives substance to the analysed rules and principles in IDL. The author concludes that the complex and multifarious nature of the international legal order, as well as the very diverse stages of development that the law of cooperation and the law of solidarity have attained in each specific area of International Law, do not allow us to conceive solidarity as a fundamental basis of the whole system. Special attention in this part is paid to the role of international cooperation within the UN human rights treaty system, especially in light of Art. 2.1 of the International Covenant on Economic, Social and Cultural Rights (ICESCR), which needs to be read

$7 \quad$ Ibid., 65 .

$8 \quad$ Ibid., 92.

9 Emmeric De Vattel, The law of nations, or principles of the law of nature, applied to the conduct and affairs of nations and sovereigns, with three early essays on the origin and nature of natural law and on luxury, Edited and with an Introduction by B. Kapossy and R. Whatmore. Liberty Fund, (2010) 263.

10 Leon Duguit, Traité de droit constitutionnel, vol 1 (1921).

11 George Scelle, Précis de droit des gens (CNRS 1932).

12 Alexandre Alvarez, La codification du droit international - ses tendances, ses bases (1912).

13 Robert Michels, Zum Problem: Solidarität und Kastenwesen. In: Probleme der Sozialphilosophie. Teubner, Leipzig (1914) 44-53. 
through two doctrinal constructs, namely, the minimum core approach ${ }^{14}$ and the tripartite classification of State obligations - the obligations to respect, protect and fulfil. ${ }^{15}$ In addition to the ICESCR, the Convention on the Rights of the Child and the Convention on the Rights of Persons with Disabilities are also analysed since they recognise various economic, social and cultural rights that are attributed to two particularly vulnerable groups of people and do not envisage the possibility of derogation in disasters. The author concludes after a thorough analysis that, absent clear and binding criteria on the distribution of responsibilities among States, the existing international cooperation framework resulting from international human rights law cannot be interpreted yet as imposing a legally binding obligation upon any particular State to provide any form of assistance. As to solidarity, it is intended as a (moral or legal) standard of action through which common interests or issues of common concern should be managed by the international community. For that reason, solidarity may be understood as a value or as a principle. Furthermore, the main features of solidarity can be identified in the following: the existence of a group whose members, tied together by certain common interests and objectives, agree to realise those interests and objectives even if this implies the postponement of individual interests and objectives. Unlike altruism, it necessarily requires a degree of group identification. Moreover, and unlike charity, it is a relationship among formal equals that is based on interdependence and a certain element of mutuality, even if not strict reciprocity. ${ }^{16}$ The ongoing progress made by international cooperation in disaster response, the author suggests, are increasingly based on such solidarity, which indeed increasingly shapes the area.

Apart from the theoretical application of international cooperation and solidarity, the author also focuses on the application of solidarity in

14 'A minimum core obligation to ensure the satisfaction of, at the very least, minimum essential levels of each of the rights is incumbent upon every State party. Thus, for example, a State party in which any significant number of individuals is deprived of essential foodstuffs, of essential primary health care, of basic shelter and housing, or of the most basic forms of education is, prima facie, failing to discharge its obligations under the Covenant. If the Covenant were to be read in such a way as not to establish such a minimum core obligation, it would be largely deprived of its raison d'être.', CESCR, General Comment 3, The nature of States parties' obligations (Art. 2, para. 1), E/1991/23, 14 December 199o, para. 10.

15 The tripartite classification of State obligations presents a series of actions by the State intended to assist individuals and communities in the enjoyment of the ICESCR's rights. See for instance: CESCR, General Comment 12, The right to adequate food, E/C.12/1999/5, 12 May 1999, para. 15 .

16 Zorzi Giustiniani (n 2) 202-203. 
practice, which is examined through the R2P doctrine (which is also analysed in Part II) and the European Union legal order. The reason for selecting the European Union legal order is understandable since it presents the most effective and incisive realisation of solidarity in disaster scenarios, in both an internal and an external dimension. Additionally, and ultimately, the EU success story in disaster management also proves that solidarity is easier to realise in a regional context. Chapter 8.2 not only highlights the existing solidarity clause, which is defined in Art. 222 of the Treaty on the Functioning of the European Union and the Union Civil Protection Mechanism, but also the novel 'rescEU' initiative, which is based on voluntariness instead of strict obligations, to conclude that solidarity in its internal dimension is a definite principle of EU law. It seems that the incentives to assist and the strong institutional framework underpinning the $\mathrm{EU}$ disaster response system is particularly effective in inducing EU Member States to aid a disaster-affected State. This, however, may change during the COVID-19 pandemic, when almost every EU Member State is battling with serious consequences of this disease. In the Asian or Caribbean region, we are witnessing substantial improvements in disaster response often influenced by the 'European example'.

Disasters do not just occur in a time of peace, but also during armed conflicts, which is the main subject of analysis in the fourth part of this book ('Civil-Military Relations in Disaster Contexts'). For this reason, contemporary IDL also regulates the presence of military personnel in the territory of a disaster-affected States, mainly through a set of non-binding tools, such as the 2007 Guidelines on The Use of Military and Civil Defence Assets In Disaster Relief (also known as the 'Oslo Guidelines'), the 2003 Guidelines on the Use of Military and Civil Defence Assets to Support United Nations Humanitarian Activities in Complex Emergencies (also known as the 'MSDA Guidelines'), and the 2013 Guidelines on the Use of Armed Escorts for Humanitarian Convoys. These normative documents pay particular attention on how to reiterate the application of the principle of 'last resort', which can be interpreted as the exceptional resort to foreign military assets and personnel to fulfil a humanitarian gap, notably where there is no comparable civilian alternative and only if the use is necessary to meet a critical humanitarian need. ${ }^{17}$ The civil-military relations in disaster response are analysed from two forms: through the use of foreign military assets in disaster response, and military or armed escorts for humanitarian convoys. Readers are provided with a real case scenario on civil-military relations in a disaster context, namely the NATO response to the 2010 Pakistan floods, where the issue of the use of foreign military arose. This

$17 \quad$ Ibid., 195 . 
case highlighted that the use of foreign military assets raises special sovereignty and security concerns for the disaster-affected States. The civil-military relations are also analysed through the lens of the Draft Articles. It is worth mentioning the author's criticism of the mentioned document regarding the use of military assets and personnel since it contains only scant references to the topic and completely ignores the last resort principle with respect to the use of military assets. This absence, coupled with the recognition of the important role of the military, which is acknowledged in the commentaries, creates a limited and vague picture of the topic that is even more disappointing for a codification work. ${ }^{18}$

'International Law in Disaster Scenarios - Applicable Rules and Principles' is a valuable contribution to the advancement of International Disaster Law literature. The work is detailed and meticulous, offering a conceptualised view on rules and principles applicable in disaster response from the perspective of disaster-affected States and assisting actors. The book is not just for scholars or practitioners beginning to explore the evolving International Disaster Law and its characteristic aspects, but also for experienced scholars in this area, who may be enriched by interdisciplinary views on disaster response.

\section{Lucia Bakošová}

Institute of International Law and European Law, Faculty of Law

Pavol Jozef Šafárik University in Košice

$18 \quad$ Ibid., 196. 